A proper dyaloge betwene a Gentillman and an Husbandman 
This page intentionally left blank 


\section{A proper dyaloge betwene a Gentillman and an Husbandman}

Edited by Douglas H. Parker

UNIVERSITY OF TORONTO PRESS

Toronto Buffalo London 
www.utppublishing.com

(C) University of Toronto Press Incorporated 1996

Toronto Buffalo London

Printed in Canada

ISBN 0-8020-0735-X

()

Printed on acid-free paper

\section{Canadian Cataloguing in Publication Data}

Main entry under title:

A proper dyaloge betwene a gentillman and an husbandman

Includes bibliographical references and index. ISBN 0-8020-0735-X

1. Reformation - Early works to 1800 .

I. Parker, Douglas H. (Douglas Harold), 1942-

BR304.P76 $1996 \quad 270.6 \quad$ C95-932003-2

University of Toronto Press acknowledges the financial assistance to its publishing program of the Canada Council and the Ontario Arts Council. 
For my father Harold Parker

and my two sisters

Beverley Simpson and Margaret Daly 
This page intentionally left blank 